\title{
Preface: The Nuances of Blackness - A Genesis and Outline
}

All books have a genesis story. In this book, it is difficult to pinpoint an originary moment, given that the issues addressed here have always been with us. Rather, the text could be said to have evolved from an informal meeting of academics, the subsequent formation of a loose collective, and a still emergent and evolving project. We thought it prudent to give this account, to allow readers to engage with what this book is about and to provide a genealogy for future (Black) scholars who wish to understand the product of our collective intentionality and how and why we chose to include particular authors, themes, and stories.

The primary genesis of this collection of voices and perspectives began at a bar in Victoria, British Columbia, at the 2013 Congress of the Humanities and Social Sciences. Around the table were all Black men colleagues, friends, former graduate chums, mentors, and mentees swapping stories: professors Boulou Ebanda de B’béri, Awad Ibrahim, Tamari Kitossa, and Handel Kashope Wright, and graduate student Emmanuel Tabi. What brought us together was the shared need for commiseration and cathartic release about our lives and careers as Black academics. Something became clear as the evening progressed: whatever our different locations across Canada, stages of career, countries of origin, sexuality, ability, home disciplines, and areas of specialization, a pattern emerged. Our experiences, despite differences, had uncanny similarities. We shared stories of joy and tribulation, of our (under) representation, including the ironic absence of women at that very gathering, and of our positions as at once privileged and marginalized subjects in the academy and in society. Invoking Stuart Hall, Handel Kashope Wright called our approach to Blackness and the intended outcome of that night the "Nuances of Blackness Project." We left the bar and that lengthy conversation with a promise to keep the discussion alive and to include other voices and perspectives and to more fully articulate 
the nuances of being a Black academic in the Canadian academy. We affirmed the need to engage in a kind of "code switching," one in which the Black academic exercises constant and sustained reflexivity, rather than taking for granted an uncomplicated identity and positionality in the academy.

The year 2014 proved to be a most generative one and particularly productive in shaping the work of the Nuances of Blackness Project. Dolana Mogadime, a professor in the Faculty of Education, Brock University, who was informed about the small Victoria gathering and was a member of the Equity and Diversity Issues Steering Committee of the Federation of the Humanities and Social Sciences (FHSS), which hosts congress, was excited enough about it to broach the topic at the FHSS. Under its vice-president (Equity Issues), Malinda S. Smith, then a professor of political science at the University of Alberta, the FHSS's Ideas-Idées blog had run a series between 2011 and 2012 on the Black experience in the Canadian academy and society, which included contributions from Carl James, Charmaine Nelson, Rinaldo Walcott, Njoki N. Wane, Zetta Elliott, Cheryl Foggo, and Adrienne Shadd, among others.

It was thought that the Nuances of Blackness Project would continue that tradition and usefully amplify that earlier work. Subsequently, with Dolana Mogadime's background work, Handel Kashope Wright and Tamari Kitossa were invited to organize an equity committee panel at the 2014 Congress of Humanities and Social Sciences at Brock University. They organized a panel titled "The Nuances of Blackness and/in the Canadian Academy," which included papers by Annette Henry (education), Afua Cooper (history), Tamari Kitossa (sociology), and Handel Kashope Wright (education). The panellists reflected on Blackness in the context of disciplinary and sociocultural diversity, as well as the theme (and eventually the title) of the present collection (see also Mogadime, 2015). At the same congress, at which the Canadian Society for the Study of Education was held, Handel Kashope Wright and Awad Ibrahim organized a parallel symposium titled "The Nuances of Blackness and/in Education." Papers were presented by Dolana Mogadime (Brock University), Jennifer Kelly (University of Alberta), Ali A. Abdi (University of Alberta), and Awad Ibrahim (University of Ottawa). With Handel Kashope Wright as chair and discussant, the session addressed topics relevant to Blackness from within the broad field of educational studies.

The group, which by then had started to think of itself as a loose collective, led by Awad Ibrahim, Tamari Kitossa, and Handel Kashope Wright, continued its engagement with Black academics at the 2015 (University of Ottawa) Congresses (including the Canadian Society for the Study of Education (CSSE) and the different SIGs (Special Interest Groups)) 
by organizing what they called "The Black Café." This initiative filled a void prior to the Black Canadian Studies Association being accepted formally as an association within the congress in 2018. Awad Ibrahim led the organization of the event. The Black Café went beyond the academy to undertake "town-gown" praxis. That symposium brought together the local Black community and Black academics attending the congress to explore issues facing the local community and to showcase academic, activist, and public intellectual work that included what coalesced as the Nuances of Blackness Project. Finally, when the project took on the air of viability and reality, it was clear to us (Ibrahim, Kitossa, and Wright) that the perspective and voices of Black women leadership would be vital to the project. Given her leading research on Blackness in the academy, and following discussions among ourselves and consultation with other Black academics in Canada, we extended an invitation to Malinda S. Smith (now at University of Calgary) to join the Nuances editorial team.

As the idea of the book took shape in tandem with the evolution of the Black Canadian Studies Association, we asked ourselves the central question: Who and what is missing among topics, prospective contributors, subject positions, disciplines, and perspectives? We then approached a wide range of academics across the country and at various stages in their academic career for prospective contributions. We are very pleased with the resulting representation of Black academics in the collection. However, we are mindful of, and regret, some gaps, omissions, and (self) exclusions. For example, not everyone at the original Victoria meeting was able to participate in all the work of the collective, including this book project. Also, several colleagues whom we invited were unable to submit their contribution, be it from intensive workload or because of their precarity as graduate students, sessional instructors, or non-tenured academics. Finally, despite our every effort to ensure their inclusion, the absence of Black scholars from the science, technology, engineering, and mathematics (STEM) disciplines is notable, as is the absence of Black scholars working in critical disability studies. The late and leading Black disabilities scholar Chris Bell $(2006,2012)$ argues that it is vital to resist the erasure of Black disabilities in disability studies (which is, in practice, white disability studies) and in Black studies (which is in essence an ableist Black studies, sans disability). This suggests the need for the inclusion of Black disability studies within both Black studies and disability studies. While Black disability as identity and as an area of studies in Canada is raised in some chapters, it is not represented as a standalone essay in the collection.

Through our rigorous editorial team review, we also had to make the difficult decision not to include some submissions. These included contributions that did not quite fit the overall theme of the book, that 
duplicated ground already covered in other chapters, or that were by authors who could not undertake substantive revisions in a timely manner. Finally, as is all too common with such edited volumes, there were some voluntary withdrawals owing to the lengthy publication process. Nevertheless, we believe the contributors in this volume foreground the breadth and depth of Black scholarship in the social sciences, humanities, and fine arts; disrupt unfounded myths about Blackness, Black scholars, and scholarship; and open further the possibilities for Black studies in the Canadian academy.

\section{Outline of the Book}

The Nuances of Blackness in the Canadian Academy is divided into four sections. Each section opens with a short commentary by a leading senior Black scholar - George J. Sefa Dei, Wisdom J. Tettey, Annette Henry, and Shirley-Anne Tate. Toward extending the conversation on Blackness in the Canadian academy, the four commentators offer insights and perspectives on key concepts, themes, and linkages in chapters contained in various sections of the book.

Part 1, "Blackness: What's in a Name?," opens the volume with an animating onto-epistemic question: What happens when a Black professor or student shows up? George Sefa Dei's commentary cites Du Bois and Fanon to show how the chapters in this section centre Blackness without having to appeal to whiteness, even as they are anchored in a radical politics of unity in Black difference. He suggests that for the authors in this section, "Blackness is too rich to be contained by a singular narrative and to be written about and from a single playbook, for in their diversity description and normativity are unified as a totality without the dogma of prescription."

In chapter 1, "The Awkward Presence of Blackness in the Canadian Academy," Handel Kashope Wright teases out the ways in which Blackness is an awkward presence in the nation and on the campuses of institutions of higher learning, the ways in which Black knowledges and ways of knowing disrupt dominant, Eurocentric ontology, epistemology, and bodies of knowledge that are taken for granted. Utilizing autobiographical vignettes, Wright illustrates and buttresses his assertion that in the language of "inclusion" and the establishment of "equity and diversity" offices and positions notwithstanding, the Black body is always already out of place, and the Black professor is the unexpected professor on the university campus.

Situated within a Black feminist experience, in chapter 2, "Exposed! The Ivory Tower's Code Noir," Delia D. Douglas is concerned with the ways in which Black women face disregard and marginalization in the 
academy that is not only racism - specifically not only anti-Black racism and not only sexism, but what she identifies as "anti-Black gendered racism." Black scholars are significantly under-represented in the academy, and Black women (at 0.7 per cent) particularly so. This underrepresentation is not only a matter of numbers but also perversely taken up as proof of the intellectual inferiority of Blacks in general, and Black women in particular. Douglas concludes that the specific doubled form of discrimination against Black women is also integral to the bolstering of "contemporary settler-colonial enslaved interpersonal relations and intellectual hierarchies."

Located squarely within philosophy of education, chapter 3, "The Precariat African-Canadian Academic: Problematic Historical Constructions, Perpetual Struggles for Recognition," by Ali A. Abdi, is a counternarrative to how the presence of the persona Africana is perceived in the academy. The persona Africana, Abdi argues, is theoretically globalized, then selectively localized, but again denied the expected full entry into the promised land of contemporary Western democratic cosmopolitanism.

Using the concepts of the "socius" and the "rhizome," and discussing an empirical ethnographic study, in chapter 4, "What Have Deleuze and Guattari Got to Do with Blackness?," Awad Ibrahim offers "a rhizomatic analysis of Blackness," where Blackness is seen not in a colonial one-dimensional way but as a multicultural, multi-ethnic, and multilingual category.

In the final chapter in part 1 , chapter 5, "Dancing with the Invisibility/ Inaudibility: Nuances of Blackness in a Francophone Context," Gina Thésée argues that the concept of Blackness does not exist in French, so, in order for her to speak as a Black francophone, she must simultaneously confront the ontological, the axiological, and the praxis. She has to engage with these dimensions, Thésée concludes, through a metaphorical dance with the invisible and the inaudible.

Part 2, "Blackness and Academic Pathways," consists of Wisdom Tetty's commentary and five chapters that explore the contradictions, nuances, and paradoxes of Blackness in relation to academic pathways into and through the academy and in engagement with the Black and wider communities.

Wisdom Tettey's commentary centres on the (1) contradictions and tensions of EDI (equity, diversity, inclusion), (2) the problematic of authentic voice and burden of representation borne by Black academics, and (3) the importance of struggle to forge alliances within and outside the university. The aim is to "facilitate the transformative change needed to realize the promise of equity and inclusion within the academy." 
In chapter 6, "Hidden Figures: Black Scholars in the Early Canadian Academy," Malinda S. Smith concerns herself with the silent and invisible ways in which stories are mobilized and taken up, and narrate Black lives. Working against the idea of the single story, Smith introduces "a talented dozen," Black hidden figures in Canadian higher education, including, among others, Abraham Beverly Walker (1851-1907), Robert Sutherland (1830-79), Sophia B. Jones (1857-1932), James R. Johnson (1876-1915), Ivy Lawrence Maynier (1921-99), and Violet Henry King (1929-82). Through these towering Black figures, who are hardly known or cited in Canada, Smith examines what is at stake in the strategic silences of submerged stories of Black Canadian excellence.

In chapter 7, "Committed to Employment Equity?: Impediments to Obtaining University Appointments," Carl E. James draws on available data to argue that despite universities' declared commitment to employment equity, they "have done little to increase the number of Black faculty members."

In chapter 8, "Black Gay Scholar and the Provocation of Promotion," Wesley Crichlow deploys an autobiographical analysis to show how the sheer presence of his body as an "out" Black gay man should be acknowledged to be a form of political activism, one that challenges the presumed "naturalness" of white heterosexual academic capitalism.

In chapter 9, "'Certain Uncertainty': Phenomenology of an African Canadian Professor," Tamari Kitossa argues that in predominantly white institutions, Black professors often find themselves between a rock and a hard place, navigating the often conflicting professional and ethical commitments. He exposes the limits of the instrumentalist presumption that Black academics owe a debt to Black communities, especially where Black cultural elites seek to disqualify the Blackness of Black academicians. Drawing on foundational decolonial thinkers Frantz Fanon and Kwame Nkrumah, he asserts that Black academics need to pursue relations of liberation beyond an essentialized notion of Blackness.

Speaking to the tensions between holding high administrative office and identifying with Blackness and Black communities, in chapter 10, "Socio-Cultural Obligations and the Academic Career: The Dual Expectations Facing Black Canadian Academics," Kay-Ann Williams and Gervan Fearon address the complex and competing interests where Black Canadian scholars meet the demand of the established institutional metrics while simultaneously meeting community engagement expectations.

Part 3, "Blackness: A Complicated Canadian Conversation," begins with a commentary from Annette Henry. She identifies how questions of what it means to be Black and to belong in and to Canada and the academy are not innocent conversation starters, but righteous demands 
calculated to affirm Black alterity and white centrality. She calls attention to deep affectivity of "blunt, curt, clipped exchanges, slips of the tongue, imposing and impolite inferences, presuppositions, and interrogations that corrode the heart and challenge the presence and integrity of the Black Canadian body and intellect in public and intellectual spaces."

The five chapters in this section explore the nuances of Blackness in complicated Canadian conversations where the politics of identity meets arts and sociality. In chapter 11, "Fitting [Out-Fitting] In," Henry Daniel whose compendium is a constant reminder of the importance of the body and the performative, including the Black body and the performance of Blackness - offers a meditation on the intersection of the poetic and the political in his encounter as a Black academic with the dean of his faculty.

In chapter 12, "The Caged Bird Still Sings in Harmony: The Academy, Spoken Word Poetry, and the Making of Community," Emmanuel Tabi tells the story of why we need to localize our scholarship while always struggling to speak the academic language. Here, the academy, a place pre-eminently of the written word, is meeting the community of the spoken word mutually imbricating sites of challenge, resistance, and solidarity on the margins.

Juliane Okot Bitek, in chapter 13, "States of Being: The Poet \& Scholar as a Black, African, \& Diasporic Woman," like Daniel and Tabi, uses the performative - in her case, poetry - to situate and ground her self-understanding at the intersections of gender, Blackness, and Africa-ness in the diaspora.

Délice Mugabo asks, in chapter 14, "Intersectionality in Blackface: When Post-Racial Nationalism Meets Black Feminism," who in francophone Canada "owns" Black studies and Black feminism. Above all, who benefits from these studies being situated in academia? If Blackness does not exist in French, Quebec included, then those who introduce intersectional studies (where "intersection" is a concept that was first introduced in Black feminism) benefit the most. To be sure, surprising to many, Mugabo contends, white francophone nationalist feminism benefits the most from Black feminism and its intersectional studies.

In chapter 15, "Re-spatializing the Boundaries of Belonging: The Subversive Blackness of Muslim Women," Jan-Therese Mendes examines how Muslim women's claim to a Black selfhood makes them walk through (so to speak) an African diasporic membership in which feeling one's Africanness is employed as an affective resource to avoid an interminable placelessness.

Part 4, "Black Pasts, Black Futurity," the final section of the volume, draws on the African indigenous conceptions of time that imagine coherence and unity in the dialectic of past and future, sutured by the present as an active moment of becoming. Centred on the politics of the 
affective, Tate writes that the authors of the chapters communicate the intensity of what it means to feel the wholeness of one's Black humanity against "suffering and self-negation even whilst they speak [their] agency with and through" suffering and self-negation. She writes that transforming Black pain into a medium for liberation is made possible by thinking about the past and present as media that enable "affective attachment and the construction of communities of Black scholars, intellectuals, and activists [who] develop ways of being beyond the anger caused by, and the pain of, anti-Blackness.

Chapter 16, "(Re)situating Black Studies at York University: Unsilencing the Past, Locating the Present, Routing Futures," is written by a group of graduate students from York University who call themselves the "York Collective." Studying the past and critically examining the present, the York Collective look into the future. They describe their efforts at centring Black studies in the academy, particularly at York University, consciously in the shadow of activism by previous Black students to establish space for Black students to move freely - intellectually and physically.

Delores V. Mullings, in chapter 17, "Community Service Learning and Anti-Blackness: The Cost of Playing with Fire on the Black Female Body," takes a similar turn as the York Collective and explores how she, as a Black feminist professor, navigates anti-Black racism and sexism from groups of white students, faculty, and staff in a social work department. Mullings's chapter, like the contribution of the York Collective, provides strategies to address the struggles and contestations faced by Black scholars in the Canadian academy.

In chapter 18, "Blackness and the Limits of Institutional Good Will," OmiSoore H. Dryden utilizes document analysis and personal narrative to make the bold argument that the dominant university policies and practices on equity, diversity, and inclusion cannot disrupt anti-Black racism. Most such policies were designed without Black people in mind, she asserts, let alone with any kind of commitment to challenge white normativity by combatting racism, racial discrimination, and racial harassment.

Like Dryden, Jennifer R. Kelly, in chapter 19, "Leadership in Neoliberal Times: A Road to Nowhere," contends that despite aspiring to leadership and administration positions, Black administrators are still subjected to anti-Black racialized power as enacted through institutional whiteness. One of Kelly's central conclusions is that neoliberalism embraces racism, especially in higher education.

Chapter 20, "Vocation of the Black Scholar in the Neoliberal Academy," is by Adelle Blackett, who calls for storytelling infused with radical love, one that advocates for the forging of radical alliance between Black scholars. The result is Black academics who together desire, advocate 
for, and struggle to achieve a united future, with our vocation seen as a labour of love that has the potential to transform the academy.

In chapter 21, "The Changing Same: Black Lives Matter, the Work of History, and the Historians' Craft," Barrington Walker, renowned historian of the Black experience in Canada, meditates on Black Lives Matter (BLM) as a contemporary expression of the long arc of the Black radical tradition in Canada and the Americas. He draws attention not only to history, but to historians as parties to the making and remaking of how events, experiences, and reality itself is understood in asserting Black humanity. Walker offers us no near-sighted hagiography of BLM, but instead from the historians' panoramic and microscopic view of Black resistance, we are treated to an appraisal, both appreciative and critical.

The final chapter of this collection, chapter 22, by Malinda S. Smith, is far from a conclusion, with its gesture toward a new imaginary. In "Charting Black Presence and Futures in the Canadian Academy," Smith offers one of the most comprehensive surveys of Canadian higher education in order to map Black presence and absence in the academy. The chapter maps Black Canadian studies academic programs, scholarship and fellowships, student associations and faculty caucuses, as well as the data on Black faculty educational attainment and income, and the representation of Black students, faculty, and administrators in the contemporary Canadian academy. She offers a clear view of the past, the ongoing struggles to establish Black Canadian studies, and the sites of struggle for charting a future that ensures that Black academics can claim their identities as part of the struggle to resist hegemonic whiteness and the oppressive homogenizing of anti-Blackness, and create enabling spaces for Black multiplicity.

\section{Conclusion: Within Multiplicity}

In curating this text, we as editors take the multiplicity of Blackness seriously. This means being attentive to articulating, naming, theorizing, and practising Blackness as an inclusive "socius" of difference, identity, and resistance. Notably, we have considered the ethno-phaulic epithet "nigger" and its "neutral" cognate, the "N-word," which occur periodically in the essays of contributors. As curators, we have no firm agreement among ourselves nor a convincing rationale to intervene in the authorial voice, political ideology, and relationship of our contributors to a word-as-deed that continues to affect their individual experience and the collective reality of Black people.

With the final preparation of Nuances of Blackness in the Canadian Academy during the COVID-19 pandemic, many of the themes explored 
throughout this volume reverberate in the broader society. That Black and racialized people are bearing the disproportionate brunt of the pandemic reflects, as a general matter, their greater exposure to harms from structural and systemic racism that circumscribes their lives, reflected in education, employment, income, and health outcomes. As post-COVID futures are being imagined and structured, we see signs already that Black, Indigenous, and racialized students might be left behind as a result of remote learning and home schooling. These dynamics place an even greater urgency on the Canadian academia to attend to the nuances of Blackness in the academy and the broader society. Unless we struggle to avert the inequitable design of the past being projected onto the future, a future that narrows even more the current sclerotic academic opportunities, structures, pathways, and pipelines, this generation will have failed in Fanonian terms "our historic mission."

Awad Ibrahim, University of Ottawa

Tamari Kitossa, Brock University

Malinda S. Smith, University of Calgary Handel Kashope Wright, University of British Columbia

\section{REFERENCES}

Bell, C. 2006. "Introducing White Disability Studies: A Modest Proposal." In The Disability Studies Reader, edited by L.J. Davis, 53-74. New York: Routledge.

Bell, C., ed. 2012. Blackness and Disability: Critical Examinations and Cultural Interventions. Ann Arbor: Michigan State University Press.

Mogadime, D. 2015. "The Nuances of Blackness and/in the Canadian Academy: A Tool for Engaging with Equity Pedagogy in the Graduate Classroom." Federation for the Humanities and Social Sciences. https:// www.ideas-idees.ca/blog/nuances-blackness-andin-canadian-academy-tool -engaging-equity-pedagogy-graduate-classroom. 